\title{
Synthesis of Heart/Dumbbell-Like CuO Functional Nanostructures for the Development of Uric Acid Biosensor
}

\author{
Zafar Hussain Ibupoto ${ }^{1,2, *}$, Aneela Tahira ${ }^{3}$, Hamid Raza ${ }^{4}$, Gulzar Ali ${ }^{2}$, Aftab Ahmed Khand ${ }^{5}$, \\ Nabila Shah Jilani ${ }^{6}$, Arfana Begum Mallah ${ }^{2}$, Cong Yu ${ }^{1}$ and Magnus Willander ${ }^{7}$ \\ 1 State Key Laboratory of Electroanalytical Chemistry, Changchun Institute of Applied Chemistry, Chinese \\ Academy of Sciences, Renmin St. 5625, Changchun 130022, China; congyu@ciac.jl.cn \\ 2 Institute of Chemistry, University of Sindh, 76080 Jamshoro, Pakistan; gulzaralichemist@gmail.com (G.A.); \\ arfana30@gmail.com (A.B.M.) \\ 3 Department of Science and Technology, Campus Norrköping, Linköping University, SE-60174 Norrköping, \\ Sweden; aneela.tahira@liu.se \\ 4 Department of Anaesthesia Liaquat, University of Medial and Health Sciences, 76080 Jamshoro, Pakistan; \\ hamid.raza@gmail.com \\ 5 School of Life Sciences, Tsinghua University, Beijing 100084, China; aftab_k97@yahoo.com \\ 6 Institute of Plant Sciences, University of Sindh, 76080 Jamshoro, Pakistan; nabila_jilani@hotmail.com \\ 7 Department of Science and Technology, Campus Norrköping, Linköping University, SE-60174 Norrköping, \\ Sweden; magnus.willander@liu.se \\ * Correspondence: zaffar_ibupoto@yahoo.com or zaffar.ibhupoto@usindh.edu.pk or zafar.ibupoto@ltu.se
}

Received: 6 July 2018; Accepted: 3 August 2018; Published: 8 August 2018

\begin{abstract}
It is always demanded to prepare a nanostructured material with prominent functional properties for the development of a new generation of devices. This study is focused on the synthesis of heart/dumbbell-like $\mathrm{CuO}$ nanostructures using a low-temperature aqueous chemical growth method with vitamin $\mathrm{B}_{12}$ as a soft template and growth directing agent. $\mathrm{CuO}$ nanostructures are characterized by scanning electron microscopy (SEM), X-ray diffraction (XRD), and X-ray photoelectron spectroscopy (XPS) techniques. CuO nanostructures are heart/dumbbell like in shape, exhibit high crystalline quality as demonstrated by XRD, and have no impurity as confirmed by XPS. Apparently, $\mathrm{CuO}$ material seems to be porous in structure, which can easily carry large amount of enzyme molecules, thus enhanced performance is shown for the determination of uric acid. The working linear range of the biosensor is $0.001 \mathrm{mM}$ to $10 \mathrm{mM}$ with a detection limit of $0.0005 \mathrm{mM}$ and a sensitivity of $61.88 \mathrm{mV} /$ decade. The presented uric acid biosensor is highly stable, repeatable, and reproducible. The analytical practicality of the proposed uric acid biosensor is also monitored. The fabrication methodology is inexpensive, simple, and scalable, which ensures the capitalization of the developed uric acid biosensor for commercialization. Also, $\mathrm{CuO}$ material can be used for various applications such as solar cells, lithium ion batteries, and supercapacitors.
\end{abstract}

Keywords: $\mathrm{CuO}$ nanostructures; vitamin $\mathrm{B}_{12}$; uric acid biosensor; potentiometric response

\section{Introduction}

Cupric oxide $(\mathrm{CuO})$ is a member of first row transition metal oxides with unique properties and advantages such as its inexpensive nature and abundance on Earth [1,2]. CuO, with its controlled shape and dimension, has received more attention due to its potential applications in various fields such as catalysis [3-8], batteries [9-12], solar cells [13,14], supercapacitors [15,16], sensors [17-19], and photodetectors [20,21]. Besides this, $\mathrm{CuO}$ as nanostructured materials can 
reveal size dependent physical and chemical properties, along with high surface area and quantum confinement [22]. Active research activities have been carried out for the synthesis of nanostructured $\mathrm{CuO}$ materials with well-defined morphology and size [2]. Thus, numerous morphologies of $\mathrm{CuO}$ are produced including nanoparticles, nanoneedles, nanowhiskers, nanowires, nanoshuttles, nanorods, nanotubes, nanoleaves, and nanoribbons via wet chemistry and physical methods [23-31]. Moreover, the complex nanostructures of $\mathrm{CuO}$ are also synthesized including nanoellipsoids [32], peanut-like nanostructures [33], nano-dendrites [34], prickly/layered microspheres [35], and dandelion-like hollow morphology [36]. The wet chemical method has more importance over other existing methods due to its low cost, simplicity, and gives a high yield of nanostructured material. Due to fascinating electrochemical properties of $\mathrm{CuO}$, it is able to be a main component of electrochemical sensors, especially potentiometric sensors [37].

Uric acid (UA) is the major product of purine metabolism and its release in urine is because of purines that are formed in the catabolism of the dietary and endogenous nucleic acid. The formation of uric acid in excess can result in precipitation in the kidney and it hinders urine excretion. The possibility of gout may be observed due to the metabolism of uric acid [38]. Several studies have shown that the formation of excessive uric acid in human blood is highly risky and can cause cardiovascular diseases [39]. Therefore, the estimation of uric acid in human physiological fluids is very important for the early diagnosis of patients who are victim to a wide range of abnormalities due to variations in purine metabolism. Currently, several uric acid biosensors are reported from different research groups [40-44]. Many of these biosensors are based on an amperometry technique [45-48]. These biosensors suffer severe disadvantages that hinder their practical applications due to their working potential at $0.7 \mathrm{~V} \mathrm{[49].} \mathrm{The} \mathrm{relatively} \mathrm{high} \mathrm{electrode} \mathrm{potential} \mathrm{makes} \mathrm{other} \mathrm{competing} \mathrm{species}$ oxidize on the surface of electrode [50]. This kind of limitation and interference can be avoided by using the potentiometric configuration that works at a negligible bias voltage as previously reported in the several studies [51-54]. The vitamin $B_{12}$ has been used as a reducing and capping agent for the preparation of noble metal nanoparticles [55].

The template assisted nanostructured materials have the advantage of fast growth nucleation and in getting controlled morphology of nanomaterials. The vitamin $\mathrm{B}_{12}$ has biocompatibility with metal oxide nanostructures, which is being presented in this work as an evident for the growth of other metal oxides. It is for the first time that vitamin $B_{12}$ is used as a growth directing agent for tuning the morphology of $\mathrm{CuO}$ nanostructures. The present study is focused on the preparation of heart/dumbbell-like $\mathrm{CuO}$ nanostructures using vitamin $\mathrm{B}_{12}$ with excellent functional properties during the development of a potentiometric uric acid biosensor for the first time.

In this research work, vitamin $\mathrm{B}_{12}$ is used as growth directing agent to control the morphology of $\mathrm{CuO}$ nanostructures using a low-temperature aqueous chemical growth method. The $\mathrm{CuO}$ nanostructured material is characterized by SEM, XRD, and XPS techniques. The functional properties of nanostructured $\mathrm{CuO}$ are demonstrated in the development of a sensitive, selective, stable, reproducible, and repeatable uric acid biosensor. The proposed potentiometric configuration was selectivity used in the determination of uric acid from the real samples, which confirms the practicality of the presented analytical device.

\section{Experimental Section}

\subsection{Chemicals Used}

Copper nitrate pentahydrate $\left(\mathrm{Cu}\left(\mathrm{NO}_{3}\right)_{2} \cdot 5 \mathrm{H}_{2} \mathrm{O}, 25 \%\right.$ ammonia, vitamin $\mathrm{B}_{12}$, uricase (E.C. 1.7.3.3), 25 units $/ 1.5 \mathrm{mg}$ from Arthrobacter globiformis, uric acid, d-glucose, ascorbic acid, glutaraldehyde, hydrochloric acid $(\mathrm{HCl})$, sodium hydroxide $(\mathrm{NaOH})$, sodium chloride $(\mathrm{NaCl})$, potassium chloride $(\mathrm{KCl})$, disodium hydrogen phosphate $\left(\mathrm{Na}_{2} \mathrm{HPO}_{4}\right)$, and potasium dihydrogen phosphate $\left(\mathrm{KH}_{2} \mathrm{PO}_{4}\right)$ were purchased from Sigma Aldrich, Jilin, china. A phosphate buffer solution of $10 \mathrm{mM}$ was made by mixing appropriate quantities of $\mathrm{NaCl}, \mathrm{KCl}, \mathrm{Na}_{2} \mathrm{HPO}_{4}$, and $\mathrm{KH}_{2} \mathrm{PO}_{4}$ in deionized water and a fixed $\mathrm{pH}$ of 7.4 for the phosphate buffer solution was obtained by adding a certain volume of $1 \mathrm{M} \mathrm{NaOH}$, 
and $1 \mathrm{M} \mathrm{HCl}$. A fresh uric acid solution was prepared in the phosphate buffer solution and kept at $4{ }^{\circ} \mathrm{C}$. The low concentration solutions were prepared using a dilution method. All the chemicals used were of analytical grade and used without further any purification.

\subsection{Synthesis of $\mathrm{CuO}$ Nanostructures Using a Low-Temperature Aqueous Chemical Growth Method with Vitamin $B_{12}$ on Gold Coated Glass Substrates}

To modify the surface of the gold-coated glass substrates with $\mathrm{CuO}$ nanostructures, a two-step methodology was followed. First, glass substrates were cleaned with acetone and deionized water in an ultrasonic bath, then dried with flowing nitrogen gas. Afterwards, the glass substrates were fixed inside the vacuum chamber of a Satis, Norrköping, Sweden (CR 725) evaporator. A thin layer of $10 \mathrm{~nm}$ of chromium was deposited on the glass substrates as an adhesive layer, followed by the $100 \mathrm{~nm}$ thickness deposition of the gold layer. In the second step, gold-coated glass substrates were again sonicated in acetone in an ultrasonic bath for $15 \mathrm{~min}$ and dried using flowing nitrogen gas, then a seed layer of $\mathrm{CuO}$ nanoparticles was spin-coated using a spin coater at $2500 \mathrm{rpm}$ for $30 \mathrm{~s}$ and seed coated substrates were annealed at $120^{\circ} \mathrm{C}$ for $30 \mathrm{~min}$ in order to get a firm binding of seed particles on the substrates. Afterwards, a $25 \mathrm{mM}$ copper nitrate pentahydrate solution was prepared in $100 \mathrm{~mL}$ deionized water and $5 \mathrm{~mL}$ of $25 \%$ ammonia was added in the solution. In order to facilitate the growth process and to get $\mathrm{CuO}$ nanostructured material of desired properties, $0.5 \mathrm{~g}$ of vitamin $\mathrm{B}_{12}$ was used as a soft template. Then, the seed-coated gold-coated glass substrates were fixed in a Teflon sample holder and kept in the growth solution. The beaker was tightly sealed using aluminum foil and kept at $95{ }^{\circ} \mathrm{C}$ for $24 \mathrm{~h}$. Afterwards, the $\mathrm{CuO}$-modified substrates were collected and washed with the deionized water in order to remove the residual particles from the surface of the nanostructured $\mathrm{CuO}$ and dried with flowing nitrogen gas.

\subsection{Material Characterization}

The morphology and structural investigations of nanostructured $\mathrm{CuO}$ were performed by SEM at a $15 \mathrm{kV}$ accelerating voltage. The crystal structure was studied using $\mathrm{X}$-ray powder diffraction (XRD) with a Phillips (PW 1729, Tokyo, Japan) powder diffractometer associated with CuK $\alpha$ radiation $(\lambda=1.5418 \AA$ at a generator voltage of $40 \mathrm{kV}$ and a current of $40 \mathrm{~mA})$. The XPS experiments were done using an ESC (A200, Sweden) spectrometer in highly vacuum of pressure of $10^{-10}$ mbar. The measurement chamber was equipped with a monochromatic $\mathrm{Al}(\mathrm{K} \alpha) \mathrm{X}$-ray source employing photons of frequency $(\mathrm{h} v=1486.6 \mathrm{eV})$.

\subsection{The Immobilization of Uricase Enzymes on the Nanostructured $\mathrm{CuO}$ and Potentiometric Measurement}

To immobilize uricase enzymes on nanostructured $\mathrm{CuO}$, first uricase solution was prepared in a phosphate buffer solution of $\mathrm{pH} 7.4$ using $(3 \mathrm{mg} / \mathrm{mL}$ uricase) and $100 \mu \mathrm{L}$ of glutaraldehyde was used as a cross-linker to avoid the self-enzyme reaction. Then, the $\mathrm{CuO}$ material was dipped in the enzyme solution for $5 \mathrm{~min}$ and the immobilized electrodes were dried in air at room temperature for $1 \mathrm{~h}$. After the immobilization, the electrodes were kept at $4{ }^{\circ} \mathrm{C}$ when not in use. The potentiometric measurements for the sensing of uric acid were done against $\mathrm{Ag} / \mathrm{AgCl}$ as a reference electrode using a Metrohm pH meter (Model 744, Beijing, China) by employing the uricase-immobilized nanostructured $\mathrm{CuO}$ material as a working electrode. All the experiments were performed at room temperature and all solutions were prepared in a $10 \mathrm{mM}$ phosphate buffer solution of $\mathrm{pH}$ 7.4. The biosensor can be reused after rinsing with the buffer solution.

\section{Results and Discussion}

\subsection{The Morphological, Structural, and Composition Studies of as Prepared CuO Nanostructures Using Vitamin $B_{12}$}

The distinctive SEM images at different magnifications for the nanostructured $\mathrm{CuO}$ material are shown in Figure 1a-d. It can be seen from the low magnification image Figure 1a that the morphology 
of $\mathrm{CuO}$ nanomaterial was heart/dumbbell-like, which is further verified at higher magnification and it exhibits a porous structure as depicted in Figure 1b. Furthermore, it can be seen that the formation of the heart/dumbbell-like morphology was comprised of thin sheets consisting of the nanoparticles on the surface as shown in Figure 1c. Figure 1d shows that the sheets in the structured $\mathrm{CuO}$ nanomaterial were well-packed with a thickness of 100 to $200 \mathrm{~nm}$. The heart/dumbbell-like morphology was well controlled using vitamin $\mathrm{B}_{12}$ as the soft template that ensured the uniform growth of the $\mathrm{CuO}$ nanomaterial. Chemically, vitamin $\mathrm{B}_{12}$ contains several polar functional groups in its structure along with a small portion of non-polar cyclic structures, but the dominancy in the growth of the $\mathrm{CuO}$ heart/dumbbell-like nanostructure is governed by the polar group that allowed for the control of the kinetic process during the growth in water and resulted a unique morphology of the $\mathrm{CuO}$ nanomaterial. However, the carbon chains of vitamin $\mathrm{B}_{12}$ were acting as a soft template for the maturing heart/dumbbell structure. The actual role of vitamin $\mathrm{B}_{12}$ in the evolution of $\mathrm{CuO}$ nanostructures is still unclear, thus we are only providing a possible role of vitamin $B_{12}$ based on the preliminary results.

a

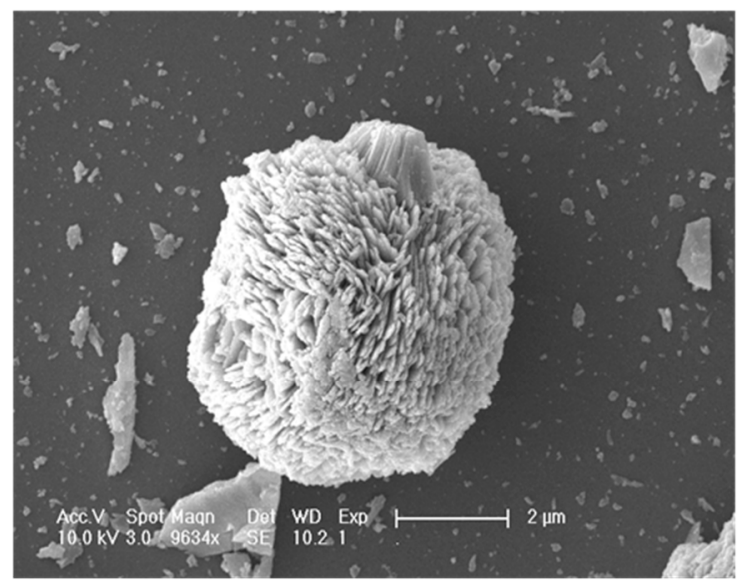

C

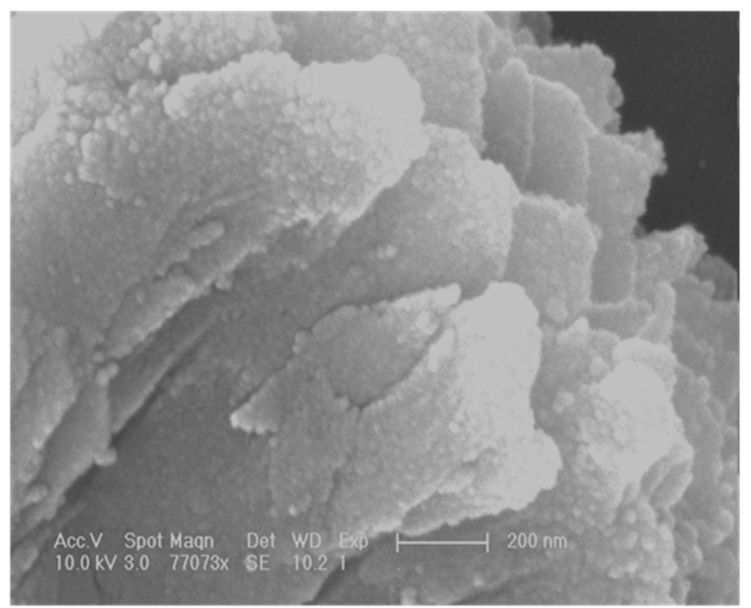

b

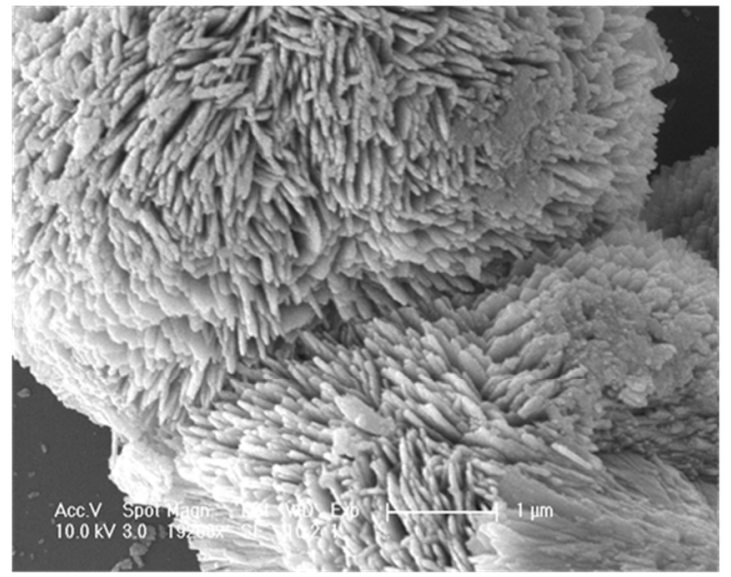

d

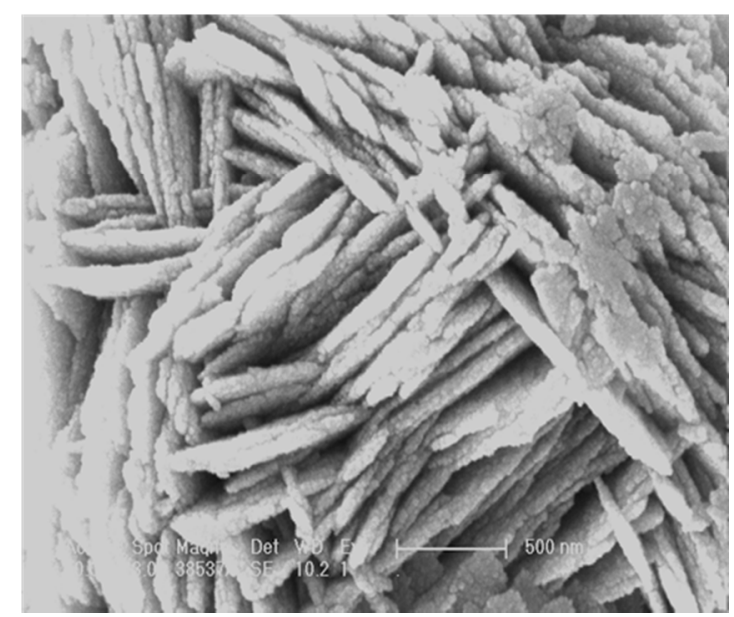

Figure 1. (a-d): SEM images of the vitamin $\mathrm{B}_{12}$ assisted synthesis of $\mathrm{CuO}$ nanostructures at different magnifications.

Figure 2 shows the XRD patterns of the nanostructured $\mathrm{CuO}$ material prepared using a low-temperature aqueous chemical growth method. The measured diffraction patterns are according 
to the standard (JCPDS card no: 96-101-1195). The CuO nanomaterial exhibited the monoclinic phase and no other peak was detected, which confirms the high purity of the $\mathrm{CuO}$ nanomaterial.

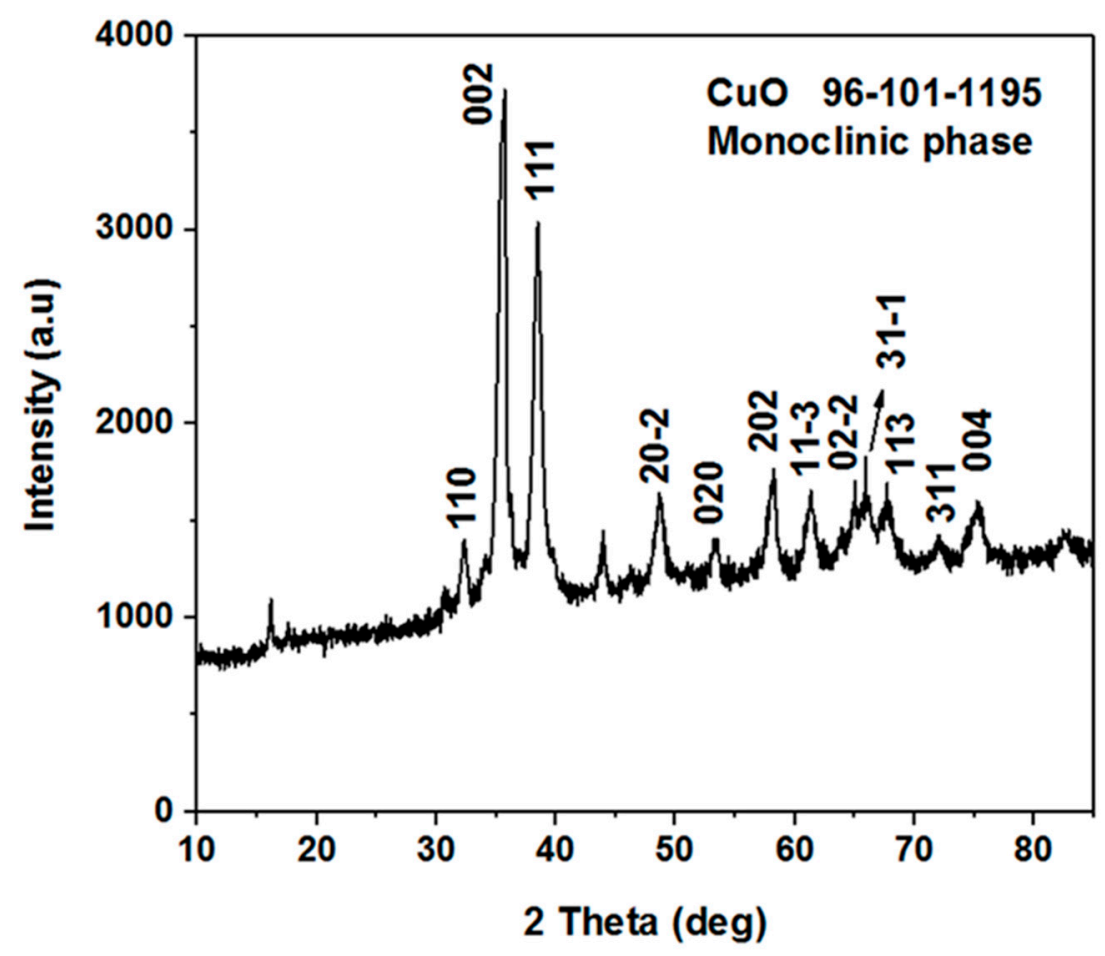

Figure 2. The XRD spectrum of the vitamin $\mathrm{B}_{12}$-assisted $\mathrm{CuO}$ nanomaterial.

The chemical composition of the nanostructured $\mathrm{CuO}$ was further investigated using XPS measurements and the obtained spectra are shown in Figure 3. Figure 3a shows the wide scan survey for the elemental composition that has two distinctive peaks, where those at 284.00 and $531.00 \mathrm{eV}$ represent $C$ 1s and $O$ 1s, respectively [56]. Additionally, the recorded peaks at 933.30, 121.10 and $77.00 \mathrm{eV}$ could be attributed to $\mathrm{Cu} 2 \mathrm{p}, \mathrm{Cu} 3 \mathrm{~s}$ and $\mathrm{Cu} 3 p$ respectively [57].

Figure $3 b, c$ discloses the XPS spectra of $\mathrm{Cu} 2 \mathrm{p}$ and $\mathrm{O} 1 \mathrm{~s}$, respectively. In the case of $\mathrm{Cu} 2 \mathrm{p}$, the recorded peak at $933.60 \mathrm{eV}$ was assigned to the binding energy of $\mathrm{Cu} 2 \mathrm{p} 3 / 2$, which is in good agreement with the published work [58], as shown in Figure 3b. Moreover, two shake-up peaks show the clear evidence for the synthesis of a $\mathrm{CuO}$ compound using a low-temperature aqueous chemical growth method. Figure 3c shows the XPS spectrum of $\mathrm{O} 1 \mathrm{~s}$ in which two peaks are observed that could be indexed to the $\mathrm{O}^{2-}$ in $\mathrm{CuO}$ at $529.47 \mathrm{eV}$ and the peak at $531.15 \mathrm{eV}$ is from the adsorbed oxygen, respectively. From composition point of view, XRD and XPS studies are in good agreement with each other. 
a
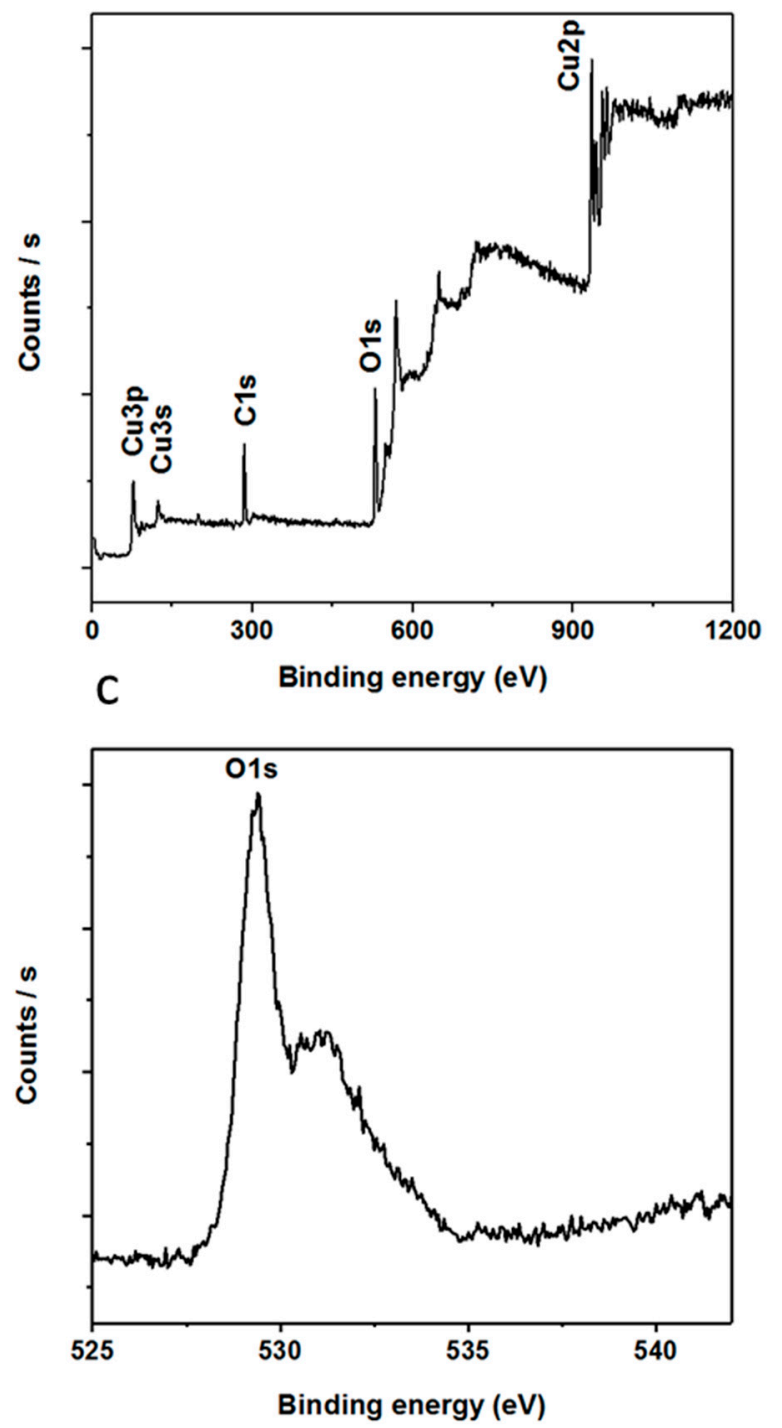

b

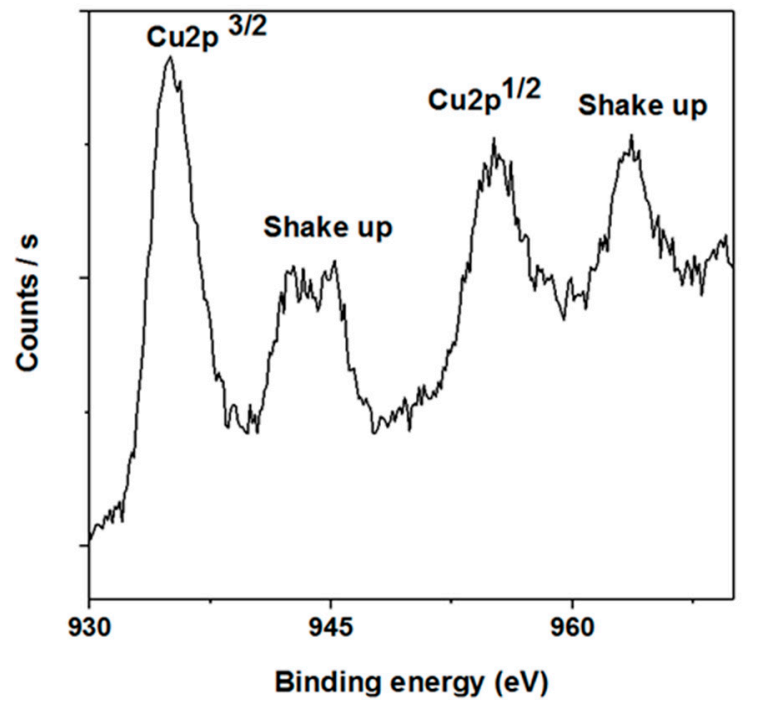

Figure 3. The XPS spectra of vitamin $\mathrm{B}_{12}$-assisted $\mathrm{CuO}$ nanostructures, (a) wide scan survey of elements present in the sample; (b) $\mathrm{Cu} 2 \mathrm{p}$; (c) $\mathrm{O}$ 1s.

3.2. The Potentiometric Response of the Proposed Uric Acid Biosensor Based on Uricase Immobilized Heart/Dumbbell-Like CuO Nanostructures

The potentiometric measurement was carried out via a two-electrode cell system using heart/dumbbell-like $\mathrm{CuO}$ nanostructures as an excellent transducer for the immobilization of uricase acting as a working electrode and silver-silver chloride $(\mathrm{Ag} / \mathrm{AgCl})$ as a reference electrode. All the experiments were performed at room temperature except for the temperature study. The output potential signal was measured in the phosphate buffer solution; thus, different concentrations of uric acid were prepared in the phosphate buffer solution of $\mathrm{pH}$ 7.4. The uricase immobilized heart/dumbbell-like $\mathrm{CuO}$ nanostructures were tested in different concentrations of uric acid ranging from $0.001 \mathrm{mM}$ to $10 \mathrm{mM}$ and the response of the biosensor was found according to Nernst's equation:

$$
\mathrm{E}=\mathrm{E}_{0}-0.05916 \mathrm{~V} / \mathrm{n} \log [\text { Reduced }] /[\text { Oxidized }]
$$

The sensing mechanics of the electrochemical uric acid biosensors was demonstrated by uricase. It was uricase that oxidized the uric acid into allantoin along with the formation of carbon dioxide 
and hydrogen peroxide. As the biosensor was working in the water, the allantoin most probably snatched a proton from the water and consequently there was the formation of an allantoinium ion that further interacted with the $\mathrm{CuO}$ nanostructures and at the surface of the $\mathrm{CuO}$ there was an accumulation of charges that were responsible for the output potential and was easily measurable by the potentiometric technique. The scale of the potential varied with respect to different concentrations of uric acid. The fabricated uric acid biosensor responded to a wide linear range of uric acid and the output potential was linearly related to the logarithmic concentrations of the uric acid, having a sensitivity of $61.88 \mathrm{mV} /$ decade, which is very close to the Nernstian slope and it indicates that the proposed configuration of sensor system was in good agreement with the Nernstian response with a regression coefficient of 0.99 . The limit of detection of the fabricated uric acid biosensor was found to be $0.0005 \mathrm{mM}$, which is estimated from the linear range as shown in Figure 4a. The repeatability was another way to notice the response of the same-immobilized $\mathrm{CuO}$ nanostructures electrode and its capability of reuse after rinsed with phosphate buffer solution and this experiment was repeated for the same electrode for three consecutive days. When the biosensor was not in use, it was kept at $4{ }^{\circ} \mathrm{C}$, and this study has shown that the biosensor has the ability to survive for a long time by maintaining the sensitivity and linear range.

a

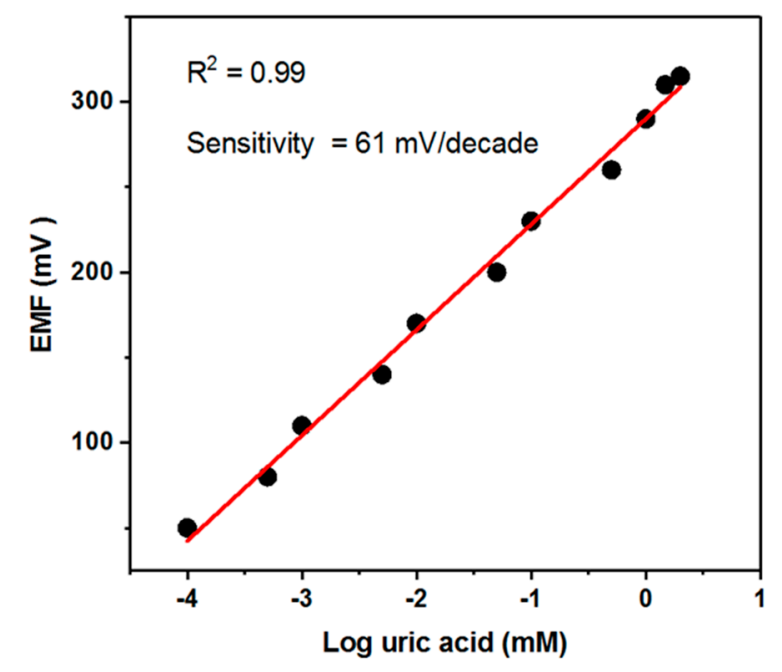

b

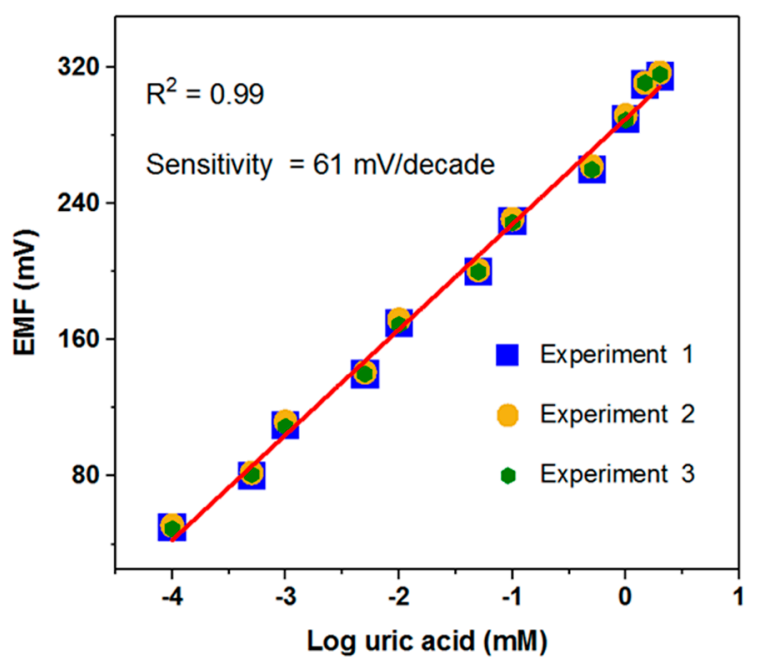

Figure 4. (a) The calibration fitting of the potentiometric uric acid biosensor for a concentration range of 0.0001-10 mM uric acid concentration; (b) the repeatability response of the uric acid biosensor in the concentration range of $0.0001-10 \mathrm{mM}$ uric acid.

For the performance evaluation of the biosensor, several parameters were investigated such as reproducibility, repeatability, selectivity, and stability. The reproducibility is an essential parameter for the performance evaluation of a fabricated biosensor. In order to ensure reliable reproducibility, six independent electrodes were fabricated by following same conditions as discussed above and the electrodes were immersed in $0.1 \mathrm{mM}$ uric acid solution and the recorded response is shown in Figure 5a, which clearly indicates the excellent inter-electrode response of the fabricated biosensor using functional nanostructured $\mathrm{CuO}$. The relative standard deviation of the electrode-to-electrode response was found to be less than $5 \%$, which shows the promising analytical features of the proposed uric acid biosensor. The presented uric acid biosensor based on $\mathrm{CuO}$ nanostructures offers a decent hosting platform for the immobilization of uricase enzyme and ultimately demonstrates the sensitive and selective response to uric acid under physiological conditions. Owing to the porous structure of the $\mathrm{CuO}$ material, the uricase molecules were allowed to penetrate within the body of the dumbbell-like nanostructures. The uricase was firmly bound to the $\mathrm{CuO}$ surface to expose 
the highly attractive features for the oxidation of uric acid. The stability of the fabricated uric acid biosensor was evaluated for four weeks and the biosensor had the ability to maintain the linear range, detection limit, and sensitivity as shown in Table 1. The biosensor could be used for more than four weeks if the storage conditions were well-controlled. Importantly, the $\mathrm{CuO}$ nanostructures-based uric acid biosensor could easily be capitalized for the monitoring of uric acid from real samples as all experiments were performed in the same physiological conditions. Therefore, a recovery method was used for the real sample analysis using the presented uric acid biosensor as the driving candidate for the sensing of uric acid with a satisfactory performance as shown in Table 2.

a
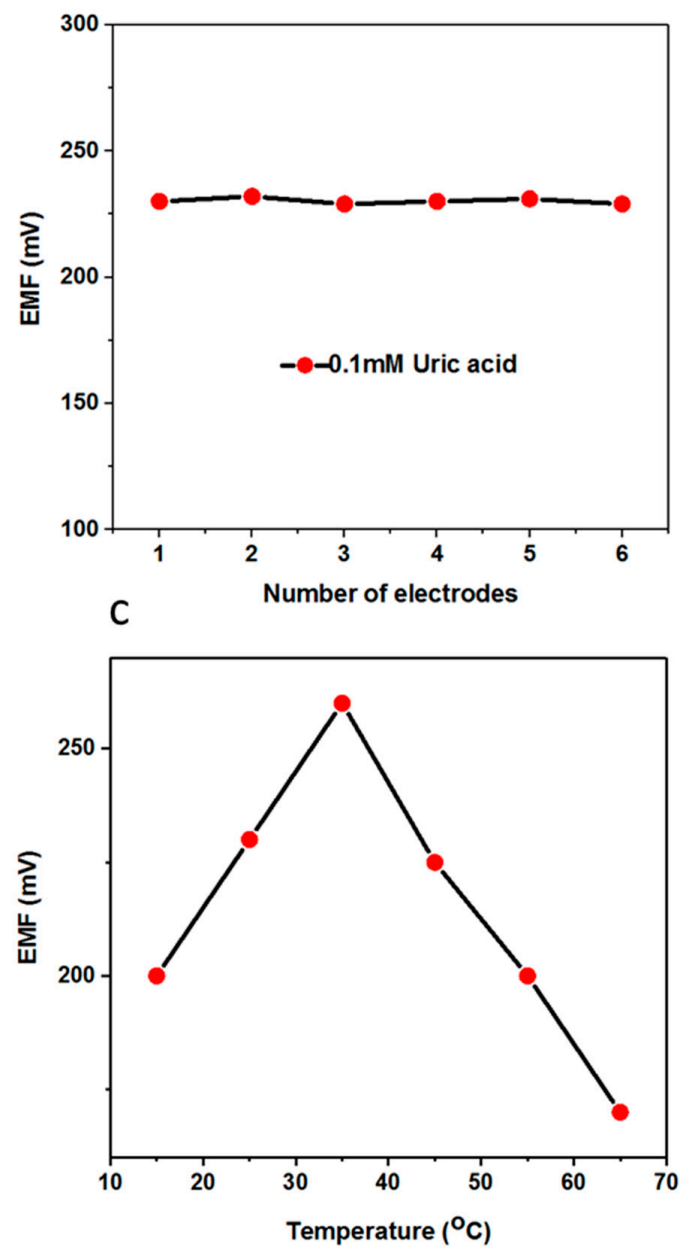

b

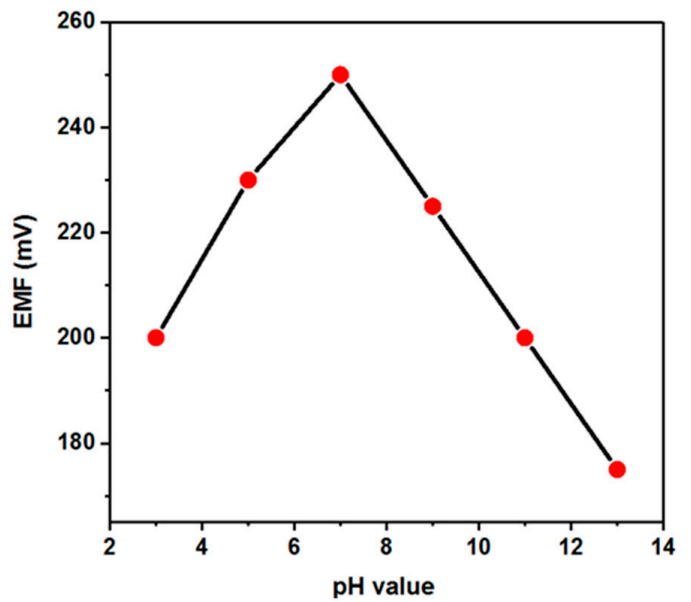

Figure 5. (a) The inter-electrode reproducibility of the uric acid biosensor in $0.1 \mathrm{mM}$ uric acid; (b) the effect of $\mathrm{pH}$ on the output potential of the uric acid biosensor in $0.5 \mathrm{mM}$ uric acid; (c) the effect of temperature on the potentiometric response of the uric acid biosensor in $0.5 \mathrm{mM}$ uric acid.

Table 1. The storage stability proposed uric acid biosensor based on $\mathrm{CuO}$ nanostructures.

\begin{tabular}{cccc}
\hline No of Weeks & Linear Range Uric Acid $(\mathbf{m M})$ & Sensitivity $(\mathbf{m V} /$ Decade) & Limit of Detection Uric Acid (mM) \\
\hline 1 & $0.001-10$ & 61.88 & 0.0005 \\
2 & $0.002-10$ & 61 & 0.0005 \\
3 & $0.001-10$ & 61.58 & 0.0004 \\
4 & $0.0025-10$ & 60 & 0.0003 \\
\hline
\end{tabular}


Table 2. The recovery method results for the analytical reliability of uric acid biosensor.

\begin{tabular}{ccc}
\hline $\begin{array}{c}\text { Spiked Concentration of } \\
\text { Uric Acid (Mm) }\end{array}$ & $\begin{array}{c}\text { Uric Acid Conc. as Quantified } \\
\text { by Proposed Biosensor }\end{array}$ & \% Uric Acid Biosensor Recovery \\
\hline 0 & 1.5 & - \\
1.8 & 2 & 111.11 \\
3.5 & 3.7 & 105.71 \\
2.5 & 2.4 & 96 \\
4.1 & 4.2 & 102.43 \\
\hline
\end{tabular}

The selectivity is the backbone of the fabricated biosensor because it is directly identifying the sensing element in the presence of other competing species. Several methods are used to monitor the selectivity of the potentiometric biosensors such as separate solution method, mixed solution method, matched potential method, and unbiased selective coefficients. In the current study, a separate solution method was used to measure selectivity coefficients according to our reported work [59] and the obtained values are fairly constant as given in Table 3. In the human blood, the common interfering species are ascorbic acid, urea, and glucose during the sensing of uric acid. Using $1 \mathrm{mM}$ uric acid and $0.1 \mathrm{mM}$ of each of the interfering species, selectivity coefficients were calculated, which are fairly constant. This study has strengthened the claim that the uric acid biosensor is highly selective for the quantification of uric acid in physiological conditions.

Table 3. The calculated selectivity coefficients for the interfering species using separate solution method using $0.1 \mathrm{mM}$ solution of each interfering substance.

\begin{tabular}{cc}
\hline Interfering Species (B) & Log K $^{\text {pot }}$ uric acid $^{\text {B }}$ \\
\hline Ascorbic acid & 2.5 \\
Urea & 1.9 \\
Glucose & 2.25 \\
\hline
\end{tabular}

\section{3. $p H$ and Temperature Studies}

The aim of this study was to find the suitable $\mathrm{pH}$ conditions under which the biosensors based on metal oxides nanostructures seemed to be stable because many of the metal oxides do not have a good figure of merit in harsh conditions, and also to ensure the physiological $\mathrm{pH}$ for which the biosensor needed to be in the driving position. $\mathrm{pH}$ has a direct influence on the activity of enzymes and the change of charges at the surface of the electrode strongly effects the output potential of the sensor. The $\mathrm{pH}$-based potentiometric signal was recorded in the $0.5 \mathrm{mM}$ uric acid solution and the biosensor showed the optimum response close to $\mathrm{pH} 7$, which is in good agreement with the performance of uricase enzyme; however, for higher $\mathrm{pH}$ values, the response of the biosensor degraded, which could be due to the loss of enzymatic activity and also the slow dissolution of metal oxides in the analyte solution as shown Figure 5b. Thus, pH 7.4 was chosen for all the measurements except the $\mathrm{pH}$ study.

Under the controlled experimental setup, the effect of different temperatures on the performance of the biosensor was examined in a $0.1 \mathrm{mM}$ uric acid solution in the temperature range of 15 to $65^{\circ} \mathrm{C}$ as shown in Figure $5 \mathrm{c}$. It can be seen that there was a gradual increase of output potential when the temperature was increased, and at $35^{\circ} \mathrm{C}$ the maximum response was recorded, which indicates that the kinetics of enzymatic activity was enhanced, and at high temperature the enzyme starts to denature and loose its activity, and thus the output signal dropped. Keeping in mind the ease of the experimental setup to avoid the solution evaporation, the measurements were therefore performed at room temperature.

The analytical results of the presented biosensor are compared with the existing uric acid biosensors in terms of linear range and sensitivity as given in Table 4. It is obvious that the proposed uric biosensor exhibited a wide linear range due to the porous nature of $\mathrm{CuO}$ nanostructures that 
carried large amounts of uricase during immobilization and provided a large surface for uric acid molecules to undergo easy oxidation.

Table 4. The comparison of presented uric acid biosensor with existing biosensors.

\begin{tabular}{|c|c|c|c|c|}
\hline Electrode Material & Technique & Linear Range mM & Sensitivity $\mathrm{mV} /$ Decade & References \\
\hline $\mathrm{ZnO}$ nanotubes & Potentiometry & $0.05-1.5$ & 68 & [61] \\
\hline $\mathrm{ZnO}$ nanorods & Amperometry & $0.005-1$ & & [63] \\
\hline $\mathrm{ZnO}$ nanoparticles & Amperometry & $0.00-1$ & & [64] \\
\hline PEDOT/Palladium & Differential pulse voltammetry & $0.007-0.011$ & & [65] \\
\hline RGO-AuNPs-CSHMs & Differential pulse voltammetry & $0.001-0.3$ & - & [68] \\
\hline $\mathrm{CuO}$ nanostrucutures & Potentiometery & $0.001-10$ & 61 & This work \\
\hline
\end{tabular}

\section{Conclusions}

In this study, heart/dumbbell-like CuO nanostructured material was synthesized uisng vitamin $\mathrm{B}_{12}$ as a growth-directing agent and template for the facilitation of the growth process using a low-temperature aqueous chemical growth method. $\mathrm{CuO}$ nanostructures were investigated uisng SEM, XPS, and XRD techniques. Using these nanostructures of $\mathrm{CuO}$, uricase enzyme was immobilized on them and used for the development of a stable, sensitive, selective, reproducible, and repeatable uric acid biosensor. The nanostructures of $\mathrm{CuO}$ are porous, which allowed the uricase molecules to reside within those pores to further allow the fast oxidation of uric acid, and finally we have a successful and an alternative analytical device for the monitoring of uric acid. The obtained results were unique and can be capitalized to commercialize the uric acid biosensor because the fabrication process is simple, cost effective, and scalable. We propose the functional properties of the prepared nanostructured $\mathrm{CuO}$ material in the field of lithium ion batteries, solar cells, and supercapacitors based on its functional properties.

Author Contributions: Z.H.I. did material synthesis and partial characterization, wrote first draft of manuscript, A.T. did the potentiometric measurement, H.R. did real samples analysis, G.A. did XRD analysis, A.A.K. contributed in the manuscript write up and biosensing characterization, N.S.J. provided the first feedback on manuscript, A.B.M did the editing of manuscript and brought the final version for publication, C.Y. and M.W. supervised the work.

Funding: National Natural Science Foundation of China, Research Fund for International Young Scientists (21550110195), Chinese Academy of Sciences President's International Fellowship Initiative. Grant No. 2015PM010

Conflicts of Interest: The authors declare no conflicts of interest.

\section{References}

1. Sang, X.; Zhang, J.; Wu, T.; Zhang, B.; Ma, X.; Peng, L.; Han, B.; Kang, X.; Liu, C.; Yang, G. Room-temperature synthesis of mesoporous $\mathrm{CuO}$ and its catalytic activity for cyclohexene oxidation. RSC Adv. 2015, 5, 67168-67174. [CrossRef]

2. Zhang, Q.; Zhang, K.; Xu, D.; Yang, G.; Huang, H.; Nie, F.; Liu, C.; Yang, C. CuO nanostructures: Synthesis, characterization, growth mechanisms, fundamental properties, and applications. Prog. Mater. Sci. 2014, 60, 208-337. [CrossRef]

3. Rout, L.; Sen, T.K.; Punniyamurthy, T. Efficient CuO nanoparticle catalyzed C-S cross coupling of thiols with iodobenzene. Angew. Chem. 2007, 46, 5583. [CrossRef] [PubMed]

4. Xu, L.; Sithambaram, S.; Zhang, Y.; Chen, C.H.; Jin, L.; Joesten, R.; Suib, S.L. Novel urchin-like CuO synthesized by a facile reflux method with efficient olefin epoxidation catalytic performance. Chem. Mater. 2009, 21, 1253-1259. [CrossRef]

5. Cao, H.; Jiang, H.F.; Zhou, X.S.; Qi, C.R.; Lin, Y.G.; Wu, J.Y.; Liang, Q.M. CuO/CNTs-catalyzed heterogeneous process: A convenient strategy to prepare furan derivatives from electron-deficient alkynes and $\alpha$-hydroxy ketones. Green Chem. 2012, 14, 2710-2714. [CrossRef] 
6. Rout, S.K.; Guin, S.; Nath, J.; Patel, B.K. An "on-water" exploration of CuO nanoparticle catalysed synthesis of 2-aminobenzothiazoles. Green Chem. 2012, 4, 2491-2498. [CrossRef]

7. Zhang, Q.; Wang, H.Y.; Jia, X.; Liu, B.; Yang, Y. Cheminform abstract: One-dimensional metal oxide nanostructures for heterogeneous catalysis. Nanoscale 2013, 5, 7175-7183. [CrossRef] [PubMed]

8. Ghosh, S.; Roy, M.; Naskar, M.K. A Facile Soft-chemical synthesis of cube-shaped mesoporous CuO with microcarpet-like interior. Cryst. Growth Des. 2014, 14, 2977-2984. [CrossRef]

9. Song, M.K.; Park, S.; Alamgir, F.M.; Cho, J.; Liu, M. Nanostructured electrodes for lithium-ion and lithium-air batteries: The latest developments, challenges, and perspectives. Mater. Sci. Eng. R 2011, 72, $203-252$. [CrossRef]

10. Wang, B.; Wu, X.L.; Shu, C.Y.; Guo, Y.G.; Wang, C.R. Synthesis of CuO/graphene nanocomposite as a high-performance anode material for lithium-ion batteries. J. Mater. Chem. 2010, 20, 10661-10664. [CrossRef]

11. Ko, S.; Lee, J.I.; Yang, H.S.; Park, S.; Jeong, U. Mesoporous CuO particles threaded with CNTs for high-performance lithium-ion battery anodes. Adv. Mater. 2012, 24, 4451-4456. [CrossRef] [PubMed]

12. Huang, H.; Liu, Y.; Wang, J.; Gao, M.; Peng, X.; Ye, Z. Self-assembly of mesoporous CuO nanosheets-CNT 3D-network composites for lithium-ion batteries. Nanoscale 2013, 5, 1785-1788. [CrossRef] [PubMed]

13. Kargar, A.; Jing, Y.; Kim, S.J.; Riley, C.T.; Pan, X.; Wang, D. ZnO/CuO heterojunction branched nanowires for photoelectrochemical hydrogen generation. ACS Nano 2013, 7, 11112-11120. [CrossRef] [PubMed]

14. Xia, Y.; Pu, X.; Liu, J.; Liang, J.; Liu, P.; Li, X.; Yu, X. CuO nanoleaves enhance the c-Si solar cell efficiency. J. Mater. Chem. A 2014, 2, 6796-6800. [CrossRef]

15. Wang, G.; Zhang, L.; Zhang, J. A review of electrode materials for electrochemical supercapacitors. Chem. Soc. Rev. 2012, 41, 797-828. [CrossRef] [PubMed]

16. Faraji, S.; Ani, F.N. Microwave-assisted synthesis of metal oxide/hydroxide composite electrodes for high power supercapacitors-A review. J. Power Sources 2014, 263, 338-360. [CrossRef]

17. Bedi, R.K.; Singh, I. Room-temperature ammonia sensor based on cationic surfactant-assisted nanocrystalline CuO. ACS Appl. Mater. Interfaces 2010, 2, 1361-1368. [CrossRef] [PubMed]

18. Taubert, A.; Stange, F.; Li, Z.; Junginger, M.; Gunter, C.; Neumann, M.; Friedrich, A. CuO nanoparticles from the strongly hydrated ionic liquid precursor (ILP) tetrabutylammonium hydroxide: Evaluation of the ethanol sensing activity. ACS Appl. Mater. Interfaces 2012, 4, 791-795. [CrossRef] [PubMed]

19. Kim, H.J.; Lee, J.H. Highly sensitive and selective gas sensors using p-type oxide semiconductors. Sens. Actuators B 2014, 192, 607-627. [CrossRef]

20. Tian, W.; Zhi, C.; Zhai, T.; Wang, X.; Liao, M.; Li, S.; Chen, S.; Golberg, D.; Bando, Y. Ultrahigh quantum efficiency of $\mathrm{CuO}$ nanoparticle decorated $\mathrm{In}_{2} \mathrm{Ge}_{2} \mathrm{O}_{7}$ nanobelt deep-ultraviolet photodetectors. Nanoscale 2012, 4, 6318-6324. [CrossRef] [PubMed]

21. Zhang, X.; Shi, W.; Zhu, J.; Kharistal, D.J.; Zhao, W.; Lalia, B.S.; Hng, H.H.; Yan, Q. High-power and high-energy-density flexible pseudocapacitor electrodes made from porous $\mathrm{CuO}$ nanobelts and single-walled carbon nanotubes. ACS Nano 2011, 5, 2013-2019. [CrossRef] [PubMed]

22. Yin, Y.; Rioux, R.M.; Erdonmez, C.K.; Hughes, S.; Somorjai, G.A.; Alivisatos, A.P. Formation of hollow nanocrystals through the nanoscale Kirkendall effect. Science 2004, 304, 711-714. [CrossRef] [PubMed]

23. Lee, S.H.; Her, Y.S.; Matijevic, E. Preparation and growth mechanism of uniform colloidal copper oxide by the controlled double-iet precipitation. J. Coll. Int. Sci. 1997, 186, 193-202. [CrossRef]

24. Jiang, X.C.; Herricks, T.; Xia, Y.N. CuO nanowires can be synthesized by heating copper substrate in air. Nano Lett. 2002, 2, 1333-1338. [CrossRef]

25. Lu, C.H.; Qi, L.M.; Yang, J.H.; Zhang, D.Y.; Wu, N.Z.; Ma, J.M. Simple template-free solution route for the controlled synthesis of $\mathrm{Cu}(\mathrm{OH})_{2}$ and $\mathrm{CuO}$ nanostructures. J. Phys. Chem. B 2004, 108, 17825-17831. [CrossRef]

26. Hou, H.W.; Xie, Y.; Li, Q. Large-scale synthesis of single-crystalline quasi-aligned submicrometer $\mathrm{CuO}$ ribbons. Cryst. Grow. Des. 2005, 5, 201-205. [CrossRef]

27. Zhao, Y.; Zhu, J.J.; Hong, J.M.; Bian, N.S.; Chen, H.Y. Microwave-induced polyol-process synthesis of copper and copper oxide nanocrystals with controllable morphology. Eur. J. Inorg. Chem. 2004, 2004, 4072-4080. [CrossRef]

28. Chen, D.; Shen, G.; Tang, K.; Zheng, H.; Qian, Y. Low-temperature synthesis of metal tungstates nanocrystallites in ethylene glycol. Mater. Res. Bull. 2003, 38, 1783-1789. [CrossRef] 
29. Yao, W.T.; Yu, S.H.; Zhou, Y.; Jiang, J.; Wu, Q.S.; Zhang, L.; Jiang, J. Formation of uniform CuO nanorods by spontaneous aggregation: Selective synthesis of $\mathrm{CuO}, \mathrm{Cu}_{2} \mathrm{O}$, and $\mathrm{Cu}$ nanoparticles by a solid-liquid phase arc discharge process. J. Phys. Chem. B 2005, 109, 14011-14016. [CrossRef] [PubMed]

30. Zhang, W.X.; Wen, X.G.; Yang, S.H.; Berta, Y.; Wang, Z.L. Single-crystalline scroll-type nanotube arrays of copper hydroxide synthesized at room temperature. Adv. Mater. 2003, 15, 822-825. [CrossRef]

31. Zhang, W.X.; Wen, X.G.; Yang, S.H. Controlled reactions on a copper surface: Synthesis and characterization of nanostructured copper compound films. Inorg. Chem. 2003, 42, 5005-5014. [CrossRef] [PubMed]

32. Zhang, Z.P.; Sun, H.P.; Shao, X.Q.; Li, D.F.; Yu, H.D.; Han, M.Y. Three-dimensionally oriented aggregation of a few hundred nanoparticles into monocrystalline architectures. Adv. Mater. 2005, 17, 42-47. [CrossRef]

33. Zhang, L.Z.; Yu, J.C.; Xu, A.W.; Li, Q.; Kwong, K.W.; Yu, S.H. Peanut-shaped nanoribbon bundle superstructures of malachite and copper oxide. J. Cryst. Grow. 2004, 266, 545-551. [CrossRef]

34. Li, S.Z.; Zhang, H.; Ji, Y.J.; Yang, D.R. CuO nanodendrites synthesized by a novel hydrothermal route. Nanotechnology 2004, 15, 1428-1432. [CrossRef]

35. Xu, J.S.; Xue, D.F. Fabrication of malachite with a hierarchical sphere-like architecture. J. Phys. Chem. B 2005, 109, 17157-17161. [CrossRef] [PubMed]

36. Liu, B.; Zeng, H.C. Mesoscale organization of $\mathrm{CuO}$ nanoribbons: Formation of dandelions. J. Am. Chem. Soc. 2004, 126, 8124-8125. [CrossRef] [PubMed]

37. Zaman, S.; Asif, M.H.; Zainelabdin, A.; Amin, G.; Nur, O.; Willander, M. CuO nanoflowers as an electrochemical $\mathrm{pH}$ sensor and the effect of $\mathrm{pH}$ on the growth. J. Electroana. Chem. 2011, 662, 421-425. [CrossRef]

38. Akyilmaz, E.; Sezgintürk, M.K.; Dinckaya, E. A biosensor based on urate oxidase-peroxidase coupled enzyme system for uric acid determination in urine. Talanta 2003, 61, 73-79. [CrossRef]

39. Alderman, M.; Aiyer, K.J.V. Uric acid: Role in cardiovascular disease and effects of losartan. Curr. Med. Res. Opin. 2004, 20, 369-379. [CrossRef] [PubMed]

40. Suzuki, H.; Arakawa, H.; Karube, I. Fabrication of a sensing module using micro machined biosensors. Biosens. Bioelectron. 2001, 16, 725-733. [CrossRef]

41. Vchiyama, S.; Sakamoto, H. Immobilization of uricase to gas diffusion carbon felt by electropolymerization of aniline and its application as an enzyme reactor for uric acid sensor. Talanta 1997, 44, 1435-1439. [CrossRef]

42. Yao, D.; Vlessidis, A.G.; Evmiridis, N.P. Microdialysis sampling and monitoring of uric acid in vivo by a chemiluminescence reaction and an enzyme on immobilized chitosan support membrane. Anal. Chim. Acta. 2003, 478, 23-30. [CrossRef]

43. Hong, H.C.; Huang, H.J. Flow injection analysis of uric acid with an uricase and horseradish peroxidase-coupled sepharose column based luminol chemiluminescence system. Anal. Chim. Acta. 2003, 499, 41-46. [CrossRef]

44. Deyhimi, F.; Ahangar, R.S. An initial-rate potentiometric method for the determination of uric acid using a fluoride ion-selective electrode. Talanta 2003, 61, 493-499. [CrossRef]

45. Zhao, C.; Wan, L.; Wang, Q.; Liu, S.; Jiao, K. Highly sensitive and selective uric acid biosensor based on direct electron transfer of hemoglobin-encapsulated chitosan-modified glassy carbon electrode. Anal. Sci. 2009, 25, 1013-1017. [CrossRef] [PubMed]

46. Bhambi, M.; Sum, G.; Malhotra, B.D.; Pundir, C.S. An amperometric uric acid biosensor based on immobilization of uricase onto polyaniline-multiwalled carbon nanotube composite film. Artif. Cells Blood Substit. Biotechnol. 2010, 38, 178-185. [CrossRef] [PubMed]

47. Kuwabata, S.; Nakaminami, T.; Ito, S.I.; Yoneyama, H. Preparation and properties of amperometric uric acid sensors. Sens. Act. B 1998, 52, 72-77. [CrossRef]

48. Hoshi, T.; Saiki, H.; Anzai, J.I. Amperometric uric acid sensors based on polyelectrolyte multilayer films. Talanta 2003, 61, 363-368. [CrossRef]

49. Harwood, G.W.J.; Pouton, C.W. Amperometric enzyme biosensors for the analysis of drugs and metabolites. Adv. Drug Del. Rev. 1996, 18, 163-191. [CrossRef]

50. Cui, G.; Yoo, J.H.; Woo, B.W.; Kim, S.S.; Cha, G.S.; Nam, H. Disposable amperometric glucose sensor electrode with enzyme-immobilized nitrocellulose strip. Talanta 2001, 54, 1105-1111. [CrossRef]

51. Liao, C.W.; Chou, J.C.; Sun, T.P.; Hsiung, S.K.; Hsieh, J.H. Preliminary investigations on a new disposable potentiometric biosensor for uric acid. IEEE Trans. Biomed. Eng. 2006, 53, 1401-1408. [CrossRef] [PubMed] 
52. Usman Ali, S.M.; Nur, O.; Willander, M.; Danielsson, B. Glucose detection with a commercial MOSFET using a $\mathrm{ZnO}$ nanowires extended gate. IEEE Trans. Nanotechnol. 2009, 8, 678-683. [CrossRef]

53. Usman Ali, S.M.; Nur, O.; Willander, M.; Danielsson, B. A fast and sensitive potentiometric glucose microsensor based on glucose oxidase coated $\mathrm{ZnO}$ nanowires grown on a thin silver wire. Sens. Act. B 2010, 145, 869-874. [CrossRef]

54. Asif, M.H.; Usman Ali, S.M.; Nur, O.; Willander, M.; Brännmark, C.; Strålfors, P.; Englund, U.H.; Elinder, F.; Danielsson, B. Functionalized ZnO-nanorod-based selective electrochemical sensor for intracellular glucose. Biosens. Bioelectron. 2010, 25, 2205-2211. [CrossRef] [PubMed]

55. Han, C.; Nagendra, V.; Baig, R.B.; Varma, R.S.; Nadagouda, M.N. Expeditious synthesis of noble metal nanoparticles using vitamin $B_{12}$ under microwave irradiation. Appl. Sci. 2015, 5, 415-426. [CrossRef]

56. Durando, M.; Morrish, R.; Muscat, A.J. Kinetics and mechanism for the reaction of hexafluoroacetyl acetone with $\mathrm{CuO}$ in supercritical carbon dioxide. J. Am. Chem. Soc. 2008, 130, 16659-16668. [CrossRef] [PubMed]

57. Dar, M.A.; Nam, S.H.; Kim, Y.S.; Kim, W.B. Synthesis, characterization, and electrochemical properties of self-assembled leaf-like CuO nanostructures. J. Solid State Electrochem. 2010, 14, 1719-1726. [CrossRef]

58. Dar, M.A.; Ahsanulhaq, Q.; Kim, Y.S.; Sohn, J.M.; Kim, W.B.; Shin, H.S. Versatile synthesis of rectangular shaped nanobat-like $\mathrm{CuO}$ nanostructures by hydrothermal method; structural properties and growth mechanism. Appl. Surface Sci. 2009, 255, 6279-6284. [CrossRef]

59. Ibupoto, Z.H.; Shah, S.M.U.A.; Khun, K.M.; Willander, M. Electrochemical L-lactic acid sensor based on immobilized $\mathrm{ZnO}$ nanorods with lactate oxidase. Sensors 2012, 12, 2456-2466. [CrossRef] [PubMed]

60. Usman Ali, S.M.; Alvi, N.H.; Ibupoto, Z.; Nur, O.; Willander, M.; Danielsson, B. Selective potentiometric determination of uric acid with uricase immobilized on ZnO nanowires. Sens. Act. B 2011, 152, $241-247$. [CrossRef]

61. Usman Ali, S.M.; Ibupoto, Z.H.; Chey, C.O.; Nur, O.; Willander, M. Functionalized ZnO nanotube arrays for the selective determination of uric acid with immobilized uricase. Chem. Sens. 2011, 19, 1-8. [CrossRef]

62. Usman Ali, S.M.; Ibupoto, Z.H.; Kashif, M.; Hashim, U.; Willander, M. A potentiometric indirect uric acid sensor based on $\mathrm{ZnO}$ nanoflakes and immobilized uricase. Sensors 2012, 12, 2787-2797. [CrossRef]

63. Zhang, F.; Wang, X.; Ai, S.; Sun, Z.; Wan, Q.; Zhu, Z.; Xian, Y.; Jin, L.; Yamamoto, K. immobilization of uricase on $\mathrm{ZnO}$ nanorods for a reagent less uric acid biosensor. Anal. Chim. Acta 2004, 519, 155-160. [CrossRef]

64. Wang, Y.T.; Yu, L.; Zhu, Z.Q.; Zhang, J.; Zhu, J.Z. Novel uric acid sensor based on enzyme electrode modified by $\mathrm{ZnO}$ nanoparticles and multiwall carbon nanotubes. Anal. Lett. 2009, 42, 775-789. [CrossRef]

65. Harish, S.; Mathiyarasu, J.; Phani, K.L.N.; Yegnaraman, V. PEDOT/palladium composite material: Synthesis, characterization and application to simultaneous determination of dopamine and uric acid. J. Appl. Electrochem. 2008, 38, 1583-1588. [CrossRef]

66. Xu, T.Q.; Zhang, Q.L.; Zheng, J.N.; Lv, Z.Y.; Wei, J.; Wang, A.J.; Feng, J.J. Simultaneous determination of dopamine and uric acid in the presence of ascorbic acid using $\mathrm{Pt}$ nanoparticles supported on reduced graphene oxide. Electrochim. Acta 2014, 115, 109-115. [CrossRef]

67. Liu, X.; Xie, L.; Li, H. Electrochemical biosensor based on reduced graphene oxide and Au nanoparticles entrapped in chitosan/silica sol-gel hybrid membranes for determination of dopamine and uric acid. J. Electroanal. Chem. 2012, 682, 158-163. [CrossRef]

68. Li, Y.; Ran, G.; Yi, W.J.; Luo, H.Q.; Li, N.B. A glassy carbon electrode modified with graphene and poly(acridine red) for sensing uric acid. Microchim. Acta 2012, 178, 115-121. [CrossRef]

(C) 2018 by the authors. Licensee MDPI, Basel, Switzerland. This article is an open access article distributed under the terms and conditions of the Creative Commons Attribution (CC BY) license (http://creativecommons.org/licenses/by/4.0/). 